University of Nebraska - Lincoln

DigitalCommons@University of Nebraska - Lincoln

Publications from USDA-ARS / UNL Faculty

U.S. Department of Agriculture: Agricultural

Research Service, Lincoln, Nebraska

$1-1-2002$

\title{
Soil health as an indicator of sustainable management
}

John W. Doran

University of Nebraska-Lincoln, jdoran1@unl.edu

Stamatis Stamatiadis

Goulandris Museum of Natural History and the GAIA Environmental Research \& Education Center, 14562

Kifissia, Greece, stam@gnhm.gr

John Haberern

Rodale Institute

Follow this and additional works at: https://digitalcommons.unl.edu/usdaarsfacpub

Part of the Agricultural Science Commons

Doran, John W.; Stamatiadis, Stamatis; and Haberern, John, "Soil health as an indicator of sustainable management" (2002). Publications from USDA-ARS / UNL Faculty. 180.

https://digitalcommons.unl.edu/usdaarsfacpub/180

This Article is brought to you for free and open access by the U.S. Department of Agriculture: Agricultural Research Service, Lincoln, Nebraska at DigitalCommons@University of Nebraska - Lincoln. It has been accepted for inclusion in Publications from USDA-ARS / UNL Faculty by an authorized administrator of DigitalCommons@University of Nebraska - Lincoln. 


\section{Agriculture Ecosystems \& Environment}

\section{Preface \\ Soil health as an indicator of sustainable management}

\section{Introduction}

Population growth, a widening gap between the rich and poor, environmental degradation, and a re-evaluation of energy use and alternatives will shape life in the 21 st century. We will be challenged to increase food supplies for a global population one-and-a-half to two times its current size. But as agricultural systems grow to meet the demands of more people, increased pressure will be placed on our natural resources: competition for land, water and energy resources from both urban and industrial sectors becomes more acute and the available land base remains static or shrinks. Under current practices increased food production will greatly increase inputs into agricultural production systems, thereby vastly increasing opportunity for environmental pollution and degradation and depletion of natural and non-renewable resources (Power, 1996). To sustain agriculture and the world for future generations, we must act now to develop production systems which rely less on non-renewable, petrochemical based resources; rely more on renewable resources from the sun for our food, fiber, and energy needs; and achieve the ecological intensification needed to meet the increased future food demand (Cassman, 1999). However, better coordination with natural processes for meeting our food and energy needs will likely require some life-style change to achieve the multiple goals of economic, ecological, and environmental sustainability. The condition of our soils ultimately determines human health by serving as the major medium for food and fiber production and a primary interface with the environment, influencing the quality of air we breathe and water we drink. Thus, there is a clear linkage between soil quality and human and environmental health. As such, the health of our soil resources is a primary indicator of the sustainability of our land management practices (Acton and Gregorich, 1995).

In this special issue, summary findings of an international workshop on "Soil Health as an Indicator of Sustainable Land Management", held June 24 and 25, 1999 at the GAIA Environmental Research and Education Center in Kifissia, Greece are presented. The objectives of this workshop were to highlight the central role of soil health in sustaining society and assuring future environmental stability and agricultural productivity and to identify critical issues and research and education needs as related to sustainable development. Oral presentations on the first day of this workshop were given by scientists and professionals from the USA, Canada, Germany, Greece, France, Moldova, Poland, Spain, and the UK.

On the second day of the workshop, participants worked together in one large group and in three small break-out groups to identify critical issues in sustainable management and to define research and education needs to address these issues. The final product was the identification of high priority research and education needs for the sustainable management of agricultural land and of the management "strategies" needed to achieve sustainability. A major challenge to us as scientists is in finding ways to translate our science into practices that people of the land can embrace to sustain both themselves and the soils and environments on which we all depend. 


\section{Plenary and invited papers: overview, transitional, research needs, applications}

Nine of the original eleven plenary papers for the workshop on "Soil Health as an Indicator of Sustainable Land Management" and two new invited papers are presented in this special issue of Agriculture, Ecosystems and the Environment. The first two papers provide an overview of the subject matter. Although not contained in this special issue, an overview paper was presented at the workshop in Greece by John Haberern, President of Rodale Institute, whom some of us refer to as the "Dean of Soil Health". This paper provided a basis for identifying the critical importance of linkages between soil health, plant health, and human health in sustainable development, excerpts of which are provided in this Preface. Another overview, presented by Dr. Wes Jackson, President of the Land Institute, is included in this special issue. It presents Natural Systems Agriculture as a radical new agricultural paradigm which relies on perennializing major crop plants and mimicking nature to develop an ecologically sound food grain production system that greatly reduces dependence on fossil fuels, soil erosion, and agrochemical contamination. John Doran provides the next overview that identifies practical tools and approaches for assessing soil quality and soil health; necessary to 'translate our science into practice' and to help land managers assess the sustainability of their land management practices.

The next three papers in this issue provide transitional information on ecological, environmental, and topographical interactions. The first paper by Johan Bouma, Wageningen University, the Netherlands, was invited to specifically provide assessment of land quality as an alternative approach to using soil quality as an indicator of sustainable land management.

Zalidis, and Stamatiadis, et al. provide a summary of the impacts of agriculture on soil degradation and water quality in the Mediterranean region. Lastly, Chuck Quimby, Director of the European Biological Control Lab, illustrates how biological control can sustain crop/land management systems by reducing inputs of non-renewable fossil energy sources.

The next four papers provide assessment of the current research status and future research needs in the area of soil quality and soil health and sustainable land management. Arshad and Martin identify critical limits for soil quality indicators in agroecosystems. Nortcliff emphasizes that international standardization of soil quality attributes and use as an index of soil quality must consider soil function, which is often varied and complex. Filip presents an international approach for assessing soil quality using ecologically related biological parameters. Stepniewski et al. present us with a view of the challenge with which we are faced when scientists working within sometimes narrow disciplinary niches are asked to apply their findings to broader ecological situations.

The last manuscript in this issue by Eigenberg et al. was specifically invited to provide one example, or application, of how a measure of soil condition can be used to assess soil quality, soil health, and sustainable management. This paper demonstrates the utility of soil electrical conductivity as a tool for assessing $\mathrm{N}$-availability from animal manure and the effectiveness of a cover crop in reducing $\mathrm{N}$-losses to the environment.

\section{Critical issues and needs for sustainable management}

Critical issues for sustainable management were first identified in a large group setting on the second day of the workshop. After identifying the major issues, high priority research needs for identifying sustainable management of agricultural land and management "strategies" to achieve long-term sustainability were defined by small groups.

On the basis of collective discussions, participants at the workshop settled on the following critical issues and needs for sustainable management:

- An ecological approach to sustainable management for multiple land uses.

- Consideration of the size of farms for which sustainable farming systems are developed.

- Communicate the critical importance of soil as related to the environment, society, and economics.

- Prescriptive and descriptive assessment of the sustainability of agricultural systems for the land manager and for scientists. 
Laid before us was the challenge to pursue a new paradigm: "To find new ways of acting to anticipate the unpredictable, to honestly communicate the right information to people, and to establish a communication link between the urban and rural sectors of society!" (Niki Goulandris, 25 June 1999).

\section{High priority research and education needs for sustainable land management}

Research and education needs were divided into three categories for discussion in breakout sessions: educational outreach; vision/research applications; and pilot ecosystem studies.

\subsection{Educational outreach}

\subsubsection{Our vision: sustaining earth and society}

4.1.1.1. Our mission and objectives. Educate ourselves and our children in ways of sharing information on ecological/environmental interactions, human impacts, and environmental restoration.

\subsubsection{Approaches.}

- Compile resources on soil, human health, and sustainability for children, researchers, farmers, policy makers, and urban/rural linkages.

- Synthesis and generation of new useful information incorporating social, economic, and environmental considerations in defining new research.

- Enhance existing information networks.

\subsection{Vision/research applications}

\subsubsection{Enhanced vision of the GAIA center}

Use the ecosystem concept as tool for research and management of land and water. Soil is the central totem of terrestrial ecosystems health. The marriage of ecology, evolutionary biology, and land management merges the descriptive with prescriptive sciences.

\subsubsection{Research approach}

Compare traditional perennial crops in polyculture under organic versus conventional technology versus studies of a natural area without crops to examine the restorative power of native plant communities.
Examples: (1) Olive trees, vines and native understory multiculture; (2) Agropastoral systems; (3) Agro-tourism; (4) Silvo-pastoral systems.

\subsection{Pilot ecosystem studies}

\subsubsection{Goal}

Identify a multifunctional approach to monitor, assess, and characterize the soil ecosystem for sustainable land management practices.

\subsubsection{Approach}

Develop methods to assess multiple functions of a given site or ecological zone that define appropriate land management for sustainable protection of soil functions. Proposing site specific soil quality indicators to monitor soil health under different management systems and enhance our understanding in key soil processes to develop methodology for sustaining productivity, biodiversity, and protecting the environment.

\section{Conclusions}

In this workshop, the links of soil quality to society and health, environmental degradation, novel ecological production systems, and the ultimate manager of the land were emphasized. The complications arising from the need to standardize key soil attributes in a multifunctional and multidimensional sustainability index were identified. It is evident that we need to increase our understanding of the linkage between soil properties, soil processes, and ecosystem functions. Only then can we improve our methodology for sustaining productivity, biodiversity, and protecting the environment. Once achieved, efficient implementation of sustainable policies requires an educational outreach to various segments of society and the translation of science into practices that can be used by the people of the land.

\section{References}

Acton, D.F., Gregorich, L.J., 1995. The Health of our Soils: Toward Sustainable Agriculture in Canada. Agric. Agri-food Can., CDR Unit, 960 Carling Ave., Ottawa, ON K1A 0C6. 
Cassman, K.G., 1999. Ecological intensification of cereal production systems: Yield potential, soil quality, and precision agriculture. Proc. Natl. Acad. Sci. 96, 5952-5959.

Power, J.F., 1996. Requirements for a sustainable agriculture for the next generation. In: Nath, B., et al. (Eds.), Proceedings of the International Conference on Environmental Pollution Vol. 1, Budapest, Hungary, 15-19 April, 1996. European Centre for Pollution Research, University of London, London E1 4NS, UK, pp. 92-98.

John W. Doran

University of Nebraska, USDA-ARS

116 Keim Hall, Lincoln, NE 68583-0934 USA

Tel.: +1-402-472-1510; fax: +1-402-472-0516

E-mail address: jdoran1@unl.edu (J.W. Doran)
Stamatis I. Stamatiadis

Goulandris Museum of Natural History and the GAIA Environmental Research \& Education Center, 13 Levidou Street 14562 Kifissia, Greece

Tel.: +30-1-8087-084; fax: +30-1-8080-674 E-mail address: stam@gnhm.gr (S.I. Stamatiadis)

John Haberern

Rodale Institute, 611 Siegfriedale Road Kutztown, PA, USA

Tel.: +1-610-683-8548; fax: +1-610-683-8548

E-mail address: jhaber@ rodaleinst.org (J. Haberern) 